CORRECTION

\title{
Correction: Targeting CXCL12/CXCR4 and myeloid cells to improve the therapeutic ratio in patient-derived cervical cancer models treated with radio-chemotherapy
}

Magali Lecavalier-Barsoum ${ }^{1}$, Naz Chaudary², Kathy Han ${ }^{2,3,4}$, Melania Pintilie ${ }^{2,5}$, Richard P. Hill ${ }^{2,3,6}$ and Michael Milosevic ${ }^{2,3,4}$ British Journal of Cancer (2019) 121:626; https://doi.org/10.1038/s41416-019-0545-z

Correction to: British Journal of Cancer (2019) 121, 249-256; https://doi.org/10.1038/s41416-019-0497-3; www.bjcancer.com; published online 26 June 2019

Since the publication of this paper, the authors have reported that an incorrect version of Fig. 1 was presented. The correct version of Fig. 1 is provided below.

Open Access This article is licensed under a Creative Commons Attribution 4.0 International License, which permits use, sharing, adaptation, distribution and reproduction in any medium or format, as long as you give appropriate credit to the original author(s) and the source, provide a link to the Creative Commons license, and indicate if changes were made. The images or other third party material in this article are included in the article's Creative Commons license, unless indicated otherwise in a credit line to the material. If material is not included in the article's Creative Commons license and your intended use is not permitted by statutory regulation or exceeds the permitted use, you will need to obtain permission directly from the copyright holder. To view a copy of this license, visit http://creativecommons. org/licenses/by/4.0/.

(c) The Author(s) 2019

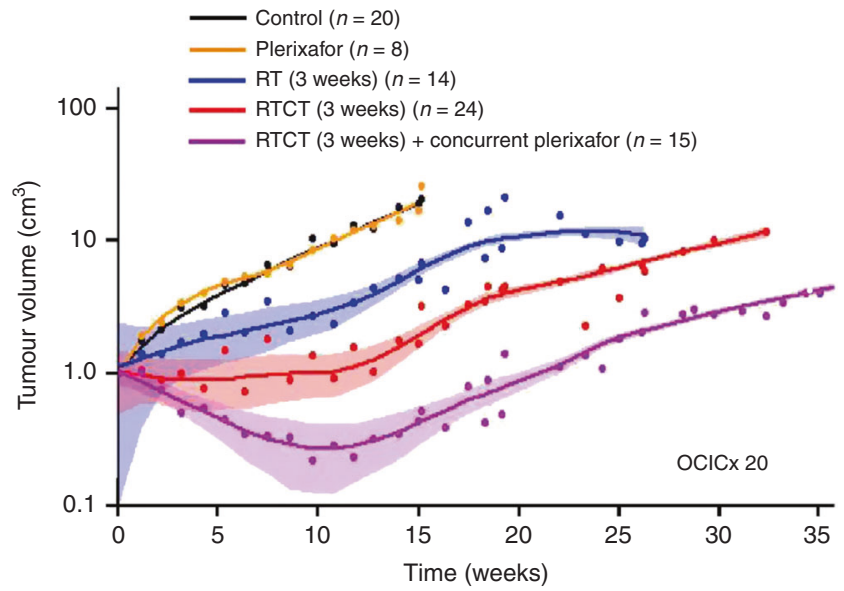

Fig. 1 Pooled data from three independent experiments showing OCICX 20 regression and regrowth with RT/RTCT (30 Gy over 3 weeks) and concurrent plerixafor for 3 weeks: no treatment controls (black), plerixafor alone (orange), RT alone (blue), RTCT (red), RTCT and concurrent plerixafor (purple). Each experiment included 5-12 mice per treatment arm. Each data point represents the mean tumour volume in up to 20 mice. A smoothed line was obtained for each treatment group using the 'loess' function in R. ${ }^{34}$ Also shown are the mean tumour volume $95 \%$ confidence intervals for the RT, RTCT and RTCT + plerixafor arms. Tumour size was monitored after treatment using weekly CT imaging and volume was estimated using orthogonal tumour dimensions, assuming an elliptical shape. Time was measured from the start of treatment. RT: Radiotherapy; RTCT: Radiotherapy and concurrent cisplatin

${ }^{1}$ Segal Cancer Centre, Jewish General Hospital and McGill University, Montreal, Canada; ${ }^{2}$ University Health Network and Princess Margaret Cancer Centre, Toronto, Canada;

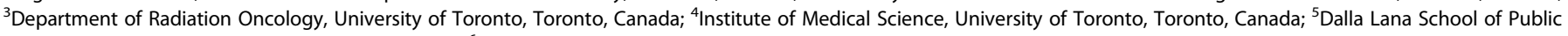
Health, University of Toronto, Toronto, Canada and ${ }^{6}$ Department of Medical Biophysics, University of Toronto, Toronto, Canada

Correspondence: Michael Milosevic (mike.milosevic@rmp.uhn.ca)

These authors contributed equally: Magali Lecavalier-Barsoum, Naz Chaudary

Published online: 9 August 2019 